\title{
PENGARUH KOMPETENSI TERHADAP KINERJA PERANGKAT NAGARI DALAM PENGELOLAAN KEUANGAN NAGARI DI KABUPATEN TANAH DATAR
}

\author{
Tania Rozanti \\ Jurusan Ilmu Administrasi Publik, Fakultas Ilmu Sosial, Universitas Negeri Padang \\ Email: tania95rozanti@gmail.com
}

\begin{abstract}
This study aimed to determine the influence of competence on performance of nagari government apparatus in managing nagari finance in Tanah Datar regency. This study was conducted with quantitative approach. The population of this study was all nagari government apparatus in Tanah Datar regency as many as 525 people consisting of nagari secretary, nagari treasurer, and five head of nagari affairs. The sample in this study consisted of 227 respondents determined with Slovin formula and Multi Stage Random Sampling technique. The data of this study were collected through questionnaire with likert scale measurement. Data of this study were analyzed with multiple linear regression test. The finding of this study indicated that the influence of knowledge sub-variables on the performance of nagari government apparatus in nagari financial management was 5.6\%; the influence of skill on the financial management was equal to 7,3\%; and the influence of attitude sub variable on the nagari financial management was equal to 8,5\%. At the same time, the influence of knowledge, skills, and attitudes on the performance of financial management was $10.3 \%$. Thus it could be concluded that the competence of nagari government apparatus consisting of knowledge, skills, and attitudes significantly influenced their performance in nagari financial management.
\end{abstract}

Keywords: Competence, job performance, nagari government, finance management

\section{Pendahuluan}

Semenjak reformasi masalah keuangan daerah dalam konteks sektor publik merupakan hal yang sering dibincangkan. Abdul Halim (2001) mendefinidsikan keuangan daerah adalah semua hak dan kewajiban yang bisa dinilai dengan uang. Baik berupa uang maupun barang yang bisa dijadikan sebagai kekayaan daerah selama itu belum dimiliki oleh negara atau daerah sesuai dengan peraturan yang berlaku.

Setelah Undang-Undang Nomor 6 Tahun 2014 tentang Desa disahkan, kesempatan yang diperoleh oleh desa untuk mengatur tata pemerintahannya sendiri serta untuk melaksanakan pembangunan dalam meningkatkan kesejahteraan dan kualitas hidup masyarakat desa sangat besar. Selanjutnya 
diharapkan kepada aparatur desa untuk lebih mandiri dalam mengelola semua SDA yang dimiliki, termasuk pengelolaan keuangan dan kekayaan milik desa. Besarnya peran desa tentunya harus disertai dengan tanggung jawab yang besar pula. Oleh sebab itu pemerintah desa harus mampu mengimplementasikan prinsip akuntabilitas dalam pemerintahannya, yang nantinya akan dipertanggung jawabkan kepada masyarakat desa sesuai dengan ketentuan.

Selanjutnya dalam Perbup Kabupaten Tanah Datar Nomor 11 Tahun 2014 mengenai Pedoman Pengelolaan Keuangan Nagari dijelaskan keuangan nagari dikelola berdasarkan asas-asas transparan, akuntabel, partisipatif serta dilakukan dengan tertib dan disiplin anggaran. Pengelolaannya dikelola dalam periode satu tahun anggaran yang dimulai dari tanggal 1 Januari sampai tanggal 31 Desember. Meskipun demikian, kenyataannya berbeda dengan yang ada di lapangan dimana masih ditemukannya persoalan-persoalan dalam pengelolaan keuangan nagari di Kabupaten Tanah Datar.

Salah satu contohnya adalah Nagari Sungayang. Masalah utama dalam pengelolaan keuangan nagari di daerah ini adalah tidak adanya transparansi aset nagari seperti kebun nagari serta keuangannya yang tidak jelas dan dana DAUN (Dana Alokasi Umum Nagari) yang sampai sekarang tidak ada kejelasannya terhadap masyarakat. Hal senada pun disampaikan oleh Anggit, selaku Kordinator LSM PENJARA (Pemantau Kinerja Aparatur Negara) untuk Kabupaten Tanah Datar, bahwa memang diduga ditemukannya indikasi kecurangan-kecurangan tersebut, mulai dari permasalahan ketidaktransparanan keuangan dan aset nagari sampai pada masalah kinerja para staf di kantor Wali Nagari Sungayang (Sumber: berita dari warta-andalas.com di akses tanggal 30 Mei 2017).

Selanjutnya di sisi lain, berdasarkan hasil wawancara dengan Sekretaris Nagari Gunuang Rajo Kecamatan Batipuah pada 21 Juli 2017, terindikasi masih ditemukannya permasalahan dalam pengelolaan keuangan nagari karena kurangnya pengetahuan dan pemahaman teknis perangkat nagari dalam pengelolaan keuangan nagari serta tidak adanya keseragaman format laporan sehingga terkendala dalam proses penyelesaian pertanggungjawaban keuangan. Disamping itu, Walinagari Gunung Rajo juga menjelaskan bahwa perangkat Nagari Gunuang Rajo kurang memiliki kompetensi dalam pengelolaan keuangan nagari. Dalam pelaksanaan pelatihan tentang pengelolaan keuangan nagari perangkat nagari tidak mengerti dengan apa yang sedang diikutinya karena materi pelatihan tersebut tidak sesuai dengan apa yang dibutuhkan oleh perangkat nagari.

Selanjutnya berdasarkan hasil penelitian yang penulis temukan bahwa terdapat hasil penelitian yang menyatakan kompetensi berpengaruh terhadap kinerja seperti hasil penelitian yang dilakukan oleh Pandey 2015 dengan hasil penelitian yang didapatkan bahwa kompetensi seperti pendidikan formal, pelatihan, dan pengalaman kerja berpengaruh positif terhadap kinerja pemerintah desa, kemudian penelitian Ika (2014) dengan hasil penelitian yang didapatkan bahwa kemampuan dan motivasi berpengaruh langsung terhadap kinerja karyawan. Namun ada juga terdapat hasil penelitian yang menyatakan bahwa kompetensi tidak berpengaruh terhadap kinerja, seperti hasil penelitian yang dilakukan oleh Septiyani (2013) dengan hasil penelitian yang didapatkan bahwa 
secara parsial kompetensi tidak berpengaruh signifikan terhadap kinerja karyawan, kemudian hasil penelitian Ratnasari (2016) dengan hasil penelitian yang didapatkan bahwa tidak terdapat berpengaruh signifikan kompetensi terhadap kinerja karyawan Departemen Quality Assurance PT. PEB Batam. Berdasarkan uraian di atas dapat ditarik kesimpulkan bahwa masih terdapat dua hasil penelitian yang berbeda dengan variabel yang sama.

Berdasarkan latar belakang masalah di atas, maka penulis telah melaksanakan penelitian di Kabupaten Tanah Datar tentang pengaruh kompetensi terhadap kinerja perangkat nagari dalam pengelolaan keuangan nagari di Kabupaten Tanah Datar. Rumusan masalah yang dikemukakan dalam penelitian ini adalah:

1. Apakah terdapat pengaruh kompetensi (yang mencakup ketiga sub varabel: pengetahuan, keterampilan, dan sikap secara bersama-sama) terhadap kinerja perangkat nagari dalam pengelolaan keuangan nagari di Kabupaten Tanah Datar?

2. Apakah terdapat pengaruh pengetahuan terhadap kinerja perangkat nagari dalam pengelolaan keuangan nagari di Kabupaten Tanah Datar?

3. Apakah terdapat pengaruh keterampilan terhadap kinerja perangkat nagari dalam pengelolaan keuangan nagari di Kabupaten Tanah Datar?

4. Apakah terdapat pengaruh sikap terhadap kinerja perangkat nagari dalam pengelolaan keuangan nagari di Kabupaten Tanah Datar?

\section{Tinjauan Kepustakaan}

\section{Kompetensi dan Kinerja}

Menurut Wibowo (2011) kompetensi merupakan kemampuan dalam melaksanakan suatu pekerjaan yang dadasari oleh keterampilan, pengetahuan dan didukung oleh sikap kerja yang dituntut oleh pekerjaan tersebut. Sementara Sagala (2009) mendefinisikan kompetensi merupakan kemampuan seseorang yang dapat terobservasi yang mencangkup pengetahuan, keterampilan, dan sikap dalam menyelesaikan suatu pekerjaan atau tugas sesuai dengan perform yang ditetapkan.

Disamping itu, Thoha, Hutapea, Parulian, dan Nurianna (2008) mengemukakan tiga komponen utama untuk dijadikan indikator mengukur kompetensi yaitu:

1) Pengetahuan, yaitu informasi yang dimiliki seseorang karyawan atau pegawai untuk melaksanakan tugas dan tanggung jawabnya sesuai dengan bidang yang digelutinya.

2) Keterampilan, yaitu suatu upaya untuk melaksanakan tugas dan tanggung jawab yang diberikan perusahaan atau organisasi kepada seorang karyawan atau pegawai dengan baik dan maksimal.

3) Sikap, adalah pola tingkah laku karyawan atau pegawai dalam melaksanakan suatu tugas dan tanggung jawabnya sesuai dengan peraturan organisasi.

Selanjutnya, Ashan (dalam Edi Sutrisno, 2015) mendefinisikan kompetensi sebagai pengetahuan, keterampilan dan kemampuan yang dimiliki oleh seseorang 
individu yang menjadi bagian dari dirinya, sehingga ia dapat melakukan perilakuperilaku kognitif, afektif, psikomotrik dengan baik. Selanjynta, Finch dan Crunkilton (dalam Edi Sutrisno, 2015) mengemukakan kompetensi sebagai penguasaan individu terhadap tugas, keterampilan, sikap, dan apresiasi yang diperlukan untuk menunjang keberhasilan.

Berdasarkan argumen di atas, maka dapat ditarik kesimpulan bahwa kompetensi adalah kemampuan yang dimiliki oleh seseorang dalam melaksanakan tugasnya yang didasari oleh pengetahuan, keterampilan dan sikap. Konsep kompetensi seperti ini lah yang digunakan dalam penelitian ini.

Selanjutnya, kinerja berasal dari terjemahan kata performance yang artinya prestasi kerja. Menurut Wibowo (2011) kinerja bukan hanya sebagai hasil kerja, tetapi juga termasuk didalamnya tentang bagaimana proses pekerjaan berlangsung. Sementara menurut Basri dan Rivai, 2005) kinerja atau prestasi kerja itu sendiri dapat didefinisikan sebagai prestasi yang dicapai oleh seseorang dalam melaksanakan tugasnya atau pekerjaanya sesuai dengan standar dan kriteria yang ditetapkan untuk pekerjaan itu.

Faktor-faktor yang dapat mempengaruhi kinerja suatu organisasi menurut Harbani Pasolong, 2010) dapat berupa kemampuan (kompetensi), kemauan, energi, teknologi, kepemimpinan, kompensasi, kejelasan tujuan, dan keamanan. Sedangkan menurut Payaman Simanjuntak (2005) kinerja individu dapat dipengaruhi oleh berbagai faktor yang intinya dapat digolongkan pada tiga kelompok, yaitu: kompetensi individu, dukungan organisasi, dan dukungan manajemen.

Banyak penelitian yang dilakukan oleh para peneliti tentang pengaruh kompetensi terhadap kinerja seseorang atau kinerja organisasi. Temuan penelitian tersebut menunjukkan hasil yang berbeda-beda. Ada hasil yang menunjukkan dukungan terhadap teori yang ada, dan ada pula yang menentang teori yang telah ada tersebut. Temuan penelitian yang mendukung teori tersebut antara lain dibuktikan oleh hasil penelitian Anak Agung Ngurah Bagus Dharmawan, dkk (2012), Ika Rahmatika (2014), Juneidy, Pandey, Juneidy, Burhanuddin Kiyai, dan Joorie Ruru (2015), Ade Nurmajaya Putra (2017), Syamsir (2017 dan 2017) yang pada umumnya mendapatkan bahwa kompetensi atau kemampuan berpengaruh terhadap kinerja pegawai dalam melaksanakan pekerjaan mereka. Sementara hasil penelitian Septiyani dan Lim Sanny (2013), Muhammad Anis Zakki (2015), dan Sri Langgeng Ratnasari (2016) mendapati bahwa variabel kompetensi tidak berpengaruh terhadap kinerja seseorang pegawai atau karyawan.

\section{Pengelolaan Keuangan Desa/Nagari}

Pengelolaan keuangan desa atau nagari tidak hanya menyangkut perlunya peraturan pendukung dan sarana-prasarana.Namun yang paling penting adalah bagaimana pengadaan SDM yang memiliki kompetensi dan komitmen serta dapat diandalkan. Setelah disahkannya Undang-undang Nomor 6 Tahun 2014 tentang Desa, maka pemerintahan desa atau nagari ikut dalam mengelola keuangan dan mempertanggungjawabkannya. Dalam UU tersebut dijelaskan bahwa Keuangan Desa adalah hak dan kewajiban desa yang dapat dinilai dengan uang serta segala 
sesuatu berupa uang dan barang yang berhubungan dengan pelaksanaan hak dan kewajiban desa.

Secara umum, peraturan yang mengatur tentang Pedoman Pengelolaan Keuangan Desa di Indonesia adalah Peraturan Menteri Dalam Negeri Nomor 113 Tahun 2014 Tentang Pedoman Pengelolaan Keuangan Desa. Dalam Peraturan tersebut ditegaskan bahwa Pengelolaan Keuangan Desa adalah keseluruhan kegiatan yang meliputi perencanaan, pelaksanaan, penatausahaan, pelaporan, dan pertanggungjawaban keuangan desa.

Menurut Undang-Undang Nomor 17 Tahun 2003 tentang Keuangan Negara, disebutkan bahwa Pengelolaan Keuangan Desa adalah keseluruhan kegiatan yang meliputi perencanaan, pelaksanaan, penatausahaan, pelaporan, dan pertanggungjawaban keuangan desa. Sementara dalam Permendagri Nomor 113 Tahun 2014 tentang Pengelolaan Keuangan Desa dijelaskan bahwa pengelolaan keuangan desa dilakukan secara transparan, akuntabel, partisipatif, serta tertib dan disiplin anggaran.

Menurut Yusuf (2016) bahwa terdapat beberapa indikator untuk mengukur kinerja kepala desa dalam pengelolaan keuangan desa dapat menggunakan atau dilihat dari hal-hal berikut:

1) Transparan, artinya masyarakat bisa mengetahui dan mendapatkan akses informasi seluasnya tentang pengelolaan keuangan desa atau APBDesa melalui prinsip keterbukaan.

2) Akuntabel, artinya prinsip tentang kewajiban seseorang untuk mempertanggungjawabkan pengelolaan dan pengendalian sumber daya dan pelaksanaan dan kebijakan yang dipercayakan kepadanya dalam rangka pencapian tujuan yang telah ditetapkan.

3) Partisipatif, artinya bahwa masyarakat diberikan kesempatan yang seluasluasnya untuk aktif terlibat dalam setiap tahapan pengelolaan keuangan desa.

4) Tertib dan disiplin anggaran, adalah mengandung makna bahwa APBDesa harus dikelola secara tepat waktu dan tepat guna yang didukung dengan bukti-bukti administrasi yang dapat dipertanggungjawabkan serta berpedoman pada peraturan yang berlaku.

Dalam rangka merealisasikan Permendagri Nomor 113 Tahun 2014 tentang pengelolaan keuangan desa tersebut, maka Pemerintah Kabupaten Tanah Datar menetapkan dan memberlakukan Peraturan Daerah Kabupaten Tanah Datar Nomor 11 Tahun 2014 tentang Pedoman Pengelolaan Keuangan Nagari. Dalam peratutan daerah ini antara lain dijelaskan Pejabat Pengelola Keuangan Nagari, yang selanjutnya disebut PPK Nagari, adalah Walinagari yang memiliki tugas melaksanakan pengelolaan APBNagari dan bertindak sebagai Bendahara Umum Nagari (BU Nagari). Dalam Perda Kabupaten Tanah Datar Nomor 11 Tahun 2014 ini juga dijelaskan bahwa pengelolaan keuangan nagari dikelola secara tertib, taat pada peraturan perundang-undangan, efektif, efisien, ekonomis, transparan, dan bertanggungjawab dengan memperhatikan asas keadilan, kepatutan dan manfaat untuk masyarakat.

Di sisi lain, berdasarkan Peraturan Daerah Kabupaten Tanah Datar No. 4 Tahun 2008 tentang Nagari, dijelaskan bahwa Perangkat Nagari terdiri dari sekretaris nagari dan perangkat nagari lainnya. Perangkat nagari lainnya terdiri 
dari dari unsur staf sekretariat nagari yang meliputi lima urusan yaitu urusan pemerintahan, pembangunan, perekonomian, kesejahteraan rakyat, serta umum dan keuangan, unsur jorong dan unsur pelaksana teknis lapangan. Mereka ini lah yang seharusnya bekerjasama dalam mengelola keuangan nagari secara transparan, akuntabel, partisipatif, serta tertib dan disiplin anggaran sebagaimana yang dikehendaki oleh Permendagri Nomor 113 tahun 2014 tersebut.

\section{Metode Penelitian}

Metode dalam penelitian ini menggunakan penelitian kuantitatif. Pendekatan yang digunakan didalam penelitian, proses, hipotesis, turun kelapangan, analisa data dan kesimpulan data sampai dengan penulisannya menggunakan aspek pengukuran, perhitungan, rumus, dan kepastian data numerik. Populasi dalam penelitian ini adalah seluruh perangkat nagari yang ada pada seluruh nagari di Kabupaten Tanah Datar. Sampel dalam penelitian ini terdiri dari 227 responden yang ditentukan dengan menggunakan rumus Slovin dan teknik penentuan sampel dilakukan dengan teknik Multi Stage Random Sampling.

Pengumpulan data dalam penelitian ini menggunakan angket dengan pengukuran skala likert dan menggunakan 4 opsi jawaban (sangat setuju, setuju, kurang setuju, dan tidak setuju). Teknik analisis data yang digunakan adalah regresi linear berganda yang diawali dengan uji asumsi klasik sebagaimana dipersyaratkan dalam uji regresi. Selain itu untuk mendapatkan gambaran umum tentang kedua variable juga digunakan frekuensi, mean, dan TCR (Tingkat Capaian Responden).

\section{Hasil Penelitian dan Pembahasan}

\section{Temuan Penelitian}

Sebagaimana telah dikemukakan dalam bagian pendahuluan, penelitian ini ingin menjawab empat pertanyaan penelitian atau rumusan masalah. Rumusan masalah pertama adalah: apakah terdapat pengaruh kompetensi (yang mencakup ketiga sub varabel: pengetahuan, keterampilan, dan sikap secara bersama-sama) terhadap kinerja perangkat nagari dalam pengelolaan keuangan nagari di Kabupaten Tanah Datar? Untuk menjawab pertanyaan penelitian ini dapat dilihat hasil analisis data temuan penelitian seperti disajikan pada Tabel 1 berikut.

Tabel 1. Pengaruh Variabel Kompetensi (Pengetahuan, keterampilan, dan sikap secara simultan) terhadap Kinerja Perangkat Nagari dalam Pengelolaan Keuangan Nagari

\begin{tabular}{lccccc}
\multicolumn{7}{c}{ Model Summary $^{\mathbf{b}}$} \\
\hline Model & R & R Square & $\begin{array}{c}\text { Adjusted R } \\
\text { Square }\end{array}$ & $\begin{array}{c}\text { Std. Error of } \\
\text { the Estimate }\end{array}$ & Durbin-Watson \\
\hline 1 & $.339^{\mathrm{a}}$ & .115 & .103 & .34461 & 1.222 \\
\hline
\end{tabular}

a. Predictors: (Constant), Kompetensi Keterampilan, Kompetensi Sikap, Kompetensi Pengetahuan

b. Dependent Variable: Pengelolaan Keuangan Nagari 
Tabel 2. Hasil Uji Anova (F) Pengaruh Variabel Kompetensi terhadap Kinerja Perangkat Nagari dalam Pengelolaan Keuangan Nagari

\begin{tabular}{llccccc}
\multicolumn{7}{c}{ ANOVA $^{\mathrm{b}}$} \\
Model & & $\begin{array}{c}\text { Sum of } \\
\text { Squares }\end{array}$ & Df & Mean Square & F & Sig. \\
\hline 1 & Regression & 3.443 & 3 & 1.148 & 9.663 & $.000^{\mathrm{a}}$ \\
& Residual & 26.483 & 223 & .119 & & \\
& Total & 29.926 & 226 & & & \\
\hline
\end{tabular}

a. Predictors: (Constant), Kompetensi Keterampilan, Kompetensi Sikap, Kompetensi Pengetahuan

b. Dependent Variable: Pengelolaan Keuangan Nagari

Berdasarkan Tabel 1 di atas dapat dijelaskan bahwa nilai Adjusted $R$ Square yang diperoleh dari analisis regresi adalah sebesar 0,103 . Artinya, besarnya pengaruh variabel kompetensi yang mencakup tiga sub variable (pengetahuan, keterampilan, dan sikap secara simultan) terhadap kinerja perangkat nagari dalam pengelolaan keuangan nagari adalah sebesar 10,3\%. Sementara sisanya sebesar 89,7\% dipengaruhi oleh faktor lain. Bila diperhatikan hasil uji Anova pada Tabel 2 di atas dapat pula dilihat bahwa hasil atau angka signifikansi pengaruh menunjukkan angka $0,000^{\mathrm{a}}$. Artinya, kebenaran kesimpulan hasil uji regresi ini dapat dipercaya sampai $100 \%$.

Selanjutnya, rumusan masalah kedua, ketiga, dan keempat yang ingin dijawab dalam penelitian ini adalah: apakah terdapat pengaruh secara sendirisendiri dari aspek pengetahuan, keterampilan, sikap (sebagai sub variabel kompetensi) terhadap kinerja perangkat nagari dalam pengelolaan keuangan nagari di Kabupaten Tanah Datar? Secara ringkas, hasil pengujian regresi untuk menjawab rumusan masalah kedua, ketiga, dan keempat tersebut dapat dilihat pada Tabel 3 berikut ini.

Tabel 3. Pengaruh Sub Variabel Pengetahuan, Keterampilan, dan Sikap secara sendiri-sendiri terhadap Kinerja Perangkat Nagari dalam Pengelolaan Keuangan Nagari

\begin{tabular}{lccrc}
\hline \multicolumn{1}{c}{ Sub Variabel } & R & R Square & $\begin{array}{c}\text { Adjusted R } \\
\text { Square }\end{array}$ & \multicolumn{1}{c}{ Sig. } \\
\hline Pengetahuan & $.245^{\mathrm{a}}$ & .060 & .056 & $.000^{\mathrm{a}}$ \\
Keterampilan & $.277^{\mathrm{a}}$ & .077 & .073 & $.000^{\mathrm{a}}$ \\
Sikap & $.298^{\mathrm{a}}$ & .089 & .085 & $.000^{\mathrm{a}}$ \\
\hline
\end{tabular}

Berdasarkan Tabel 3 di atas dapat dipahami bahwa, nilai Adjusted $R$ Square untuk sub variabel pengetahuan adalah sebesar 0,056 . Hal ini berarti bahwa pengaruh pengetahuan terhadap pengelolaan keuangan nagari adalah sebesar 5,6\%. Sedangkan sisanya sebesar $94,4 \%$ dipengaruhi oleh variabel lain. Selanjutnya nilai Adjusted $R$ Square untuk sub variabel keterampilan adalah sebesar 0,073. 
Hal ini berarti bahwa pengaruh keterampilan terhadap pengelolaan keuangan nagari adalah sebesar 7,3\% dan sisanya sisanya sebesar $92,7 \%$ dipengaruhi oleh variabel lain. Sedangkan nilai Adjusted $R$ Square untuk sub variabel sikap adalah sebesar 0,085. Hal ini berarti bahwa pengaruh sikap terhadap pengelolaan keuangan nagari adalah sebesar $8,5 \%$ dan sisanya sisanya sebesar $91,5 \%$ dipengaruhi oleh variabel lain. Selain itu, bila diperhatikan hasil uji Anova pada hasil atau angka signifikansi pengaruh menunjukkan angka $0,000^{\mathrm{a}}$ untuk ketigatiga sub-variabel. Ini berarti bahwa kebenaran kesimpulan hasil uji regresi ini dapat pula dipercaya sampai $100 \%$.

\section{Pembahasan}

Hasil penelitian tentang pengaruh kompetensi terhadap kinerja perangkat nagari dalam pengelolaan keuangan nagari di Kabupaten Tanah Datar telah membuktikan bahwa terdapat pengaruh kompetensi terhadap kinerja perangkat nagari dalam pengelolaan keuangan nagari di Kabupaten Tanah Datar, baik secara simultan maupun secara sendiri-sendiri dari ketiga sub variabel kompetensi, yaitu pengetahuan, keterampilan, dan sikap. Secara bersama-sama pengaruh pengetahuan, keterampilan dan sikap terhadap kinerja perangkat nagari dalam pengelolaan keuangan nagari di Kabupaten Tanah Datar menghasilkan angka signifikansi 0,000 dan nilai Adjust $R$ Square sebesar 0,103 sehingga dapat dikatakan bahwa kontribusinya adalah sebesar $10,3 \%$ dan nilai $\mathrm{R}$ sebesar 0,339 yang berarti bahwa kekuatan variabel kompetensi terhadap kinerja perangkat nagari dalam pengelolaan keuangan nagari di Kabupaten Tanah Datar sebesar $33,9 \%$. Berdasarkan penjelasan tersebut dapat disimpulkan bahwa baik secara parsial maupun secara bersama-sama kompetensi memiliki pengaruh secara signifikan terhadap kinerja perangkat nagari dalam pengelolaan keuangan nagari di Kabupaten Tanah Datar.

Selanjutnya hasil uji secara sendiri-sendiri pengaruh sub-variabel pengetahuan (X1), keterampilan (X2), dan sikap (X3) terhadap pengelolaan keuangan nagari menghasilkan angka signifikansi masing-masing sebesar 0,000 dan nilai Adjust $R$ Square masing-masing sebesar $0,056 \quad(5,6 \%)$ untuk pengetahuan, $0,073(7,3 \%)$ untuk keterampilan, dan $0,085(8,5 \%)$ untuk sub variabel sikap. Oleh karenanya dapat dikatakan bahwa kontribusi pengetahuan terhadap pengelolaan keuangan nagari sebesar 5,6\%, keterampilan sebesar 7,3\%, dan sikap sebesar 8,5\%.

Dengan memperhatikan hasil penelitian ini dapat dipahami bahwa hasil penelitian ini dapat membuktikan dan ikut memperkuat teori-teori dan temuan penelitian yang sudah ada, seperti dikemukakan oleh Wibowo (2011) kompetensi merupakan kemampuan dalam melaksanakan suatu pekerjaan yang dadasari oleh keterampilan, pengetahuan dan didukung oleh sikap kerja yang dituntut oleh pekerjaan tersebut. Hal ini berarti kompetensi yang baik tentu akan memengaruhi kinerja seseorang menjadi lebih baik karena kompetensi merupakan karakteristik dasar yang dimiliki seseorang yang berpengaruh langsung terhadap, atau dapat memprediksikan kinerja yang baik. 
Disamping itu, hasil penelitian ini juga ikut mendukung dan memperkuat teori yang dikemukakan oleh Simanjuntak (2005) yang menyatakan bahwa kinerja dipengaruhi oleh banyak faktor yang dapat digolongkan pada tiga kelompok yaitu kompetensi individu, dukungan organisasi, dan dukungan manajemen. Dari ketiga faktor yang mempengaruhi kinerja yang diungkapkan di atas dapat diketahui bahwa kompetensi merupakan faktor utama yang mempengaruhi kinerja selain dukungan organisasi dan dukungan manajemen.

\section{Penutup}

Berdasarkan hasil penelitian dan pembahasan yang telah diuraikan di atas, dapat disimpulkan bahwa:

1. Sub-variabel pengetahuan (X1) terhadap pengelolaan keuangan nagari memiliki nilai Adjust $R$ Square 0,056, sehingga dapat dikatakan bahwa kontribusi pengetahuan terhadap pengelolaan keuangan nagari di Kabupaten Tanah Datar adalah sebesar 5,6\%. Sub-variabel keterampilan (X2) terhadap pengelolaan keuangan nagari memiliki nilai Adjust $R$ Square 0,073 sehingga dapat dikatakan bahwa kontribusi keterampilan terhadap pengelolaan keuangan nagari di Kabupaten ada sebesar 7,3\%. Sedangkan sub-variabel Sikap (X3) terhadap pengelolaan keuangan nagari memiliki nilai Adjust $R$ Square sebesar 0,085 dan dengan demikian dapat pula dikatakan bahwa kontribusi sikap terhadap pengelolaan keuangan nagari di Kabupaten Tanah Datar ada sebesar 8,5\%.

2. Baik secara simultan maupun secara sendiri-sendiri pengaruh pengetahuan, keterampilan, dan sikap terhadap kinerja perangkat nagari dalam pengelolaan keuangan nagari menunjukkan angka signifikansi 0,000. Dengan nilai signifikansinya lebih kecil dari 0,05 ini maka Ho ditolak dan Ha diterima. Dengan demikian dapat disimpulkan bahwa terdapat pengaruh yang signifikan variabel kompetensi terhadap kinerja perangkat nagari dalam pengelolaan keuangan nagari di Kabupaten Tanah Datar dan kebenaran kesimpulan ini dapat dipercaya sampai pada $100 \%$.

Berdasarkan hasil penelitian dan kesimpulan yang telah diuaraikan di atas, maka penulis mengemukakan saran-saran sebagai berikut:

1. Hasil penelitian ini menunjukan bahwa sub-variabel pengetahuan, keterampilan, dan sikap berpengaruh secara signifikan terhadap kinerja perangkat nagari dalam pengelolaan keuangan nagari di Kabupaten Tanah Datar dengan kontribusi sebesar 10,3\% (secara sendiri-sendiri pengaruh pengetahuan $5,6 \%$, keterampilan 7,3\%, dan sikap $8,5 \%$ ). Sisanya $89,7 \%$ yang belum dimaksimalkan oleh Perangkat Nagari di Kabupaten Tanah Datar. Dengan demikian disarankan kepada setiap perangkat nagari agar lebih memperhatikan dan meningkatkan kompetensi yang mencakup aspek pengetahuan, keterampilan, dan sikap dalam pengelolaan keuangan nagari. Meskipun pengaruhnya tidak begitu besar (hanya 10,3\%) namun peningkatan kompetensi perangkat nagari dalam pengelolaan keuangan nagari ini penting dilakukan demi menigkatkan kinerja pemerintahan nagari secara keseluruhan. 
2. Peneliti menyadari bahwa hasil penelitian ini masih memiliki kelemahan tertentu, maka dari itu diharapkan kepada peneliti selanjutnya untuk lebih menyempurnakan penelitian ini dengan cara melakukan penelitian yang lebih mendalam dan dengan melibatkan berbagai variabel lain yang mungkin juga dapat berpengaruh terhadap kinerja pengelolaan keuangan nagari di Kabupaten Tanah Datar.

\section{DAFTAR KEPUSTAKAAN}

\section{Buku dan Jurnal:}

Abdul Haim. (2001). Manajemen Keuangan Daerah. Yogyakarta: UPP AM YKPN.

Anak Agung Ngurah Bagus Dhermawan dkk. (2012). "Pengaruh Motivasi, Lingkungan Kerja, Kompetensi dan Kompensasi Terhadap Kepuasan Kerja dan Kinerja Pegawai di Lingkungan Kantor Dinas Pekerjaan Umum Provinsi Bali”. Jurnal Manajemen, Strategi Bisnis dan Kewirausahaan. Vol. 6.

Basri \& Rivai. (2005). Performance Appraisal: Sistem yang Tepat Untuk Menilai Kinerja Karyawan dan Meningkatkan Daya Saing Perusahaan, Jakarta: PT. Raja Grafindo Persada.

Edi Sutrisno. (2015). Manajemen Sumber Daya Manusia. Jakarta: Kencana.

Harbani Pasolong. (2010). Kepemimpinan Birokrasi. Bandung: Alfabeta.

Pandey, Juneidy, Burhanuddin Kiyai, dan Joorie Ruru. (2015). "Pengaruh Kompetensi Kerja Terhadap Kinerja Aparat Pemerintah Desa: Studi di Kecamatan Pineleng Kabupaten Minahasa". Jurnal Administrasi Publik. No 31, Vol III. ejournal.unsrat.ac.id/index.php/JAP/article/download/8745/ 8306. Diakses tanggal 11 Januari 2017.

Putra, Ade Nurmajaya. (2017). "Pengaruh Kompetensi, Kompensasi dan Kepuasan Kerja Terhadap Kinerja Kepala Desa dalam Pengelolaan Keuangan Desa di Kabupaten Kerinci”. Tesis. Padang: Magister Administrasi Publik, FIS UNP Padang.

Payaman Simanjuntak. (2005). Manajemen dan Evaluasi Kinerja. Jakarta: Lembaga Penerbit Fakultas Ekonomi Universitas Indonesia.

Ratnasari, Sri Langgeng. (2016). "Pengaruh Kompetensi dan Kompensasi Terhadap Kinerja Karyawan Departemen Quality Assurance PT. PEB Batam". Prosiding. Seminar Nasional Ekonomi dan Bisnis \& Call For Paper FEB UMSIDA 2016. https://www.google.co.id/ search?dcr $=0$ \&ei $=$ QDBXWq

G5IYfbvATT64rYAw\&q=Sri+Langgeng ++ Ratnasari $+\% 282016 \%$

Sagala Rivai. (2009). Manajemen Sumber Daya Manusia untuk Perusahaan: Dari Teori ke Praktik. Edisi Kedua. Jakarta: Rajawali Pers. 
Septiyani dan Lim Sanny. (2013). Analisis Pengaruh Kompetensi Individu dan Motivasi Terhadap Kinerja Karyawan PT. Beta Setia Mega. Binus Business Review Vol. 4 No. 1 Mei 2013: 274-282.

Syamsir. (2017). "Model Pembinaan Kapasitas Aparatur Pemerintahan Nagari dalam Pengelolaan Keuangan Nagari di Kabupaten Tanah Datar Provinsi Sumatera Barat. Laporan Penelitian. Padang: Universitas Negeri Padang.

Syamsir. (2017). "The Effect of Competence and Job Satisfaction on Job Performance of The "Nagari" Government Apparatus in Managing Village Finances in The District of Tanah Datar. Makalah diseminarkan pada Konferensi Internasional IRCEB, Malang 11-12 Desember 2017.

Thoha Hutapea Parulian dan Nurianna. (2008). Kompetensi Plus : Teori, Desain, Kasus dan Penerapan untuk HR dan Organisasi yang Dinamis. Jakarta: Gramedia Pustaka Utama.

Wibowo. (2011). Manajemen Kinerja Edisi Ketiga. Jakarta: PT Raja Gravindo Persada.

Yusuf, Murtiono. (2016). Modul Tata Kelola Keuangan Desa. Yogyakarta: Infest.

Zakki, Anis Muhammad. (2015). “Analisis Pengaruh Kompetensi terhadap Kinerja Karyawan pada BMT TAMZIS Area Yogyakarta. Skripsi. Yogyakarta: UIN Sunan Kalijaga.

\section{Peraturan Perundang-undangan}

Undang-Undang Nomor 6 Tahun 2014 Tentang Desa

Peraturan Menteri Dalam Negeri Nomor 113 Tahun 2104 Tentang Pedoman Pengelolaan Keuangan Desa

Peraturan Daerah Kabupaten Tanah Datar Nomor 4 Tahun 2008 Tentang Nagari

\section{Referensi dari Intrenet}

http://wartaandalas.com/berita-wali-nagari-sungayang-di-duga-tersandung-kasuspenggelapan-dana-nagari.html\#ixzz4fdPZJEyE 